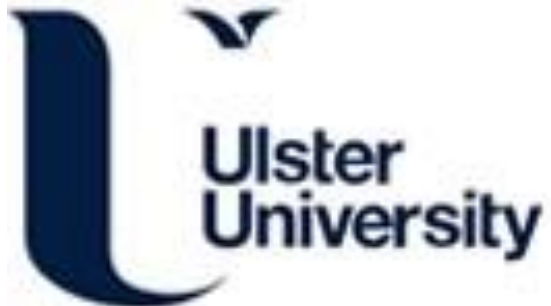

\section{Multi-Agent Interactions for Ambient Assisted Living}

McNaull, J., Augusto, J. C., Mulvenna, M., \& McCullagh, PJ. (2011). Multi-Agent Interactions for Ambient Assisted Living. In Unknown Host Publication (pp. 310-313). IEEE Computer Society.

https://doi.org/10.1109/IE.2011.56

Link to publication record in Ulster University Research Portal

\section{Published in:}

Unknown Host Publication

Publication Status:

Published (in print/issue): 01/01/2011

DOI:

10.1109/IE.2011.56

\section{Document Version}

Publisher's PDF, also known as Version of record

\section{General rights}

Copyright for the publications made accessible via Ulster University's Research Portal is retained by the author(s) and / or other copyright owners and it is a condition of accessing these publications that users recognise and abide by the legal requirements associated with these rights.

\section{Take down policy}

The Research Portal is Ulster University's institutional repository that provides access to Ulster's research outputs. Every effort has been made to ensure that content in the Research Portal does not infringe any person's rights, or applicable UK laws. If you discover content in the Research Portal that you believe breaches copyright or violates any law, please contact pure-support@ulster.ac.uk. 


\title{
Multi-Agent Interactions for Ambient Assisted Living
}

\author{
James McNaull, Juan Carlos Augusto, Maurice Mulvenna and Paul McCullagh \\ School of Computing and Mathematics \\ University of Ulster at Jordanstown, \\ Newtownabbey, Belfast, UK
}

\begin{abstract}
Multi-Agent Systems provide the software to analyse and understand the data emanating from sensor networks in support of Ambient Assisted Living. We report on the implementation of interfaces which are controlled and dynamically updated by such a multi-agent system. The system can respond to changes of context and tailor interventions and interactions based on the individual who is interacting with the interface.
\end{abstract}

Keywords-Ambient Intelligence; Context Aware Computing; Ambient Assisted Living; Human Computer Interaction;

\section{INTRODUCTION}

This paper illustrates how a multi-agent system (MAS) may provide assistance and support by offering interventions through a controllable user interface. The intersection of Human Computer Interaction (HCI) [1], Ambient Assisted Living (AAL) [2] and Context Aware Computing has forged a research area of ambient assisted interfaces. It is envisaged that the MAS may an appropriate tool to provide assistance and support in AAL scenarios through worthwhile and meaningful interventions. Underlying the MAS is multi-agent framework. This has been designed to allow adaption of the assistance and support that is offered based on:

1. The currently detected context, such as time of day

2. Specific user requirements

3. The current location of users of the AAL system

4. The users current situation

5. The situation surrounding an event

The paper is organised as follows. Section 2 provides an overview of Ambient Intelligence (Aml), Assisted Living and the related research. Section 3 outlines the research ideas that are currently being implemented. Section 4 provides an overview of the multi-agent framework and details the agents including the Sensor, Profile, Context, Intervention and Interaction Agents. An Assisted Living (AL) scenario that provides a snapshot of an individual's routine during a set time period is provided to aid in illustrating what may occur in a real AL scenario. Table 1 outlines sample requirements that an individual may have and these are currently being investigated as part of the MAS development. The events from the scenario that may trigger sensor data to be stored, sensor events to be sent and contextual, intervention, interaction and profile messages to be exchanged between the agents, are detailed by table 2 . The implementation and functionality are discussed and results and observations detailed. Section 5 outlines future work. Lastly a conclusion is provided.

\section{RELATED RESEARCH}

Ambient intelligence may be integrated into the home, work and medical environments to provide intelligent context aware assistance. An overview of the research area of Ambient Intelligence is provided by [3]. Examples of functionality that Aml may have are outlined by [4] as "Context aware, anticipatory, provide natural interaction, and be adaptive." Through processing of contextual data that has been detected and carrying out analysis for erroneous events it may be possible to provide "relevant information and/or services to the user, where relevancy depends on the user's task." [5] AAL technologies are technologies that have added ambient intelligence that may enable them to adapt to changes in context [6]. This may enable the ambient assisted living technologies to carry out specific interactions and therapeutic interventions that reflect the current detected changes in context and they may have an awareness of their surroundings and the ability to function independently. AAL technologies may offer capabilities including "sensitive, responsive, adaptive, transparent, ubiquitous, and intelligent." [7]. A number of the issues that may be encountered with current (AL) solutions are outlined by [8] as having a limited ability to describe the current situation as they are not aware of the current context, do not provide support in emergencies and are often difficult to operate. Further examples are discussed in [9] and [10]. There are numerous research projects being conducted which touch upon context aware computing, assisted living and multi model interaction. Examples include research that has been conducted by [11] where they outline a framework that provides adaptive service provisioning in an intelligent home environment. A system that interprets user spoken dialogue and recognition of writing to control aspects of a home environment are discussed by [12]. A framework for developing multi-model interfaces for providing older people with meal reminders is detailed by [13] and a framework for adapting interactive systems based on user behaviour is discussed by [14].

\section{THE RESEARCH IDEAS}

The current research idea is the implementation of a multiagent system that may be able to offer the following functionality: Control and dynamically update an interface based on the current user's requirements, which is set by a profile agent. Detect the current context and any changes of context that may occur. Be aware of the time of day so that time critical interventions and interactions may be offered at the correct time. Through the Interface carry out interactions 
and offer interventions that have been determined based on the current detected context, time of day, known user requirements and current situation. To enable the interface to move from a mobile device to a static wall mounted device based on the current requirements, detected context and location of the user and the interface. To enable the interface to follow the user and continue interactions which may have been started in another location.

\section{Iv. MULTI-AGENT ARCHITECTURE}

We are programming our Multi-Agent system (MAS) as a team of agents who cooperate to translate contextual information into context infused interactions that may help to assist an individual in an AL scenario. Figure 1 details the conceptual architecture which consists of a Sensor Agent, Context Agent, Intervention Agent and an Interface Agent and Profile Agent. Our Multi-Agent System is currently being implemented in Jade [15]. The persons profile is set (A), in relation to the scenario this is set to the "no specific requirements' profile. The person is monitored by the sensors that are located in the environment (B).

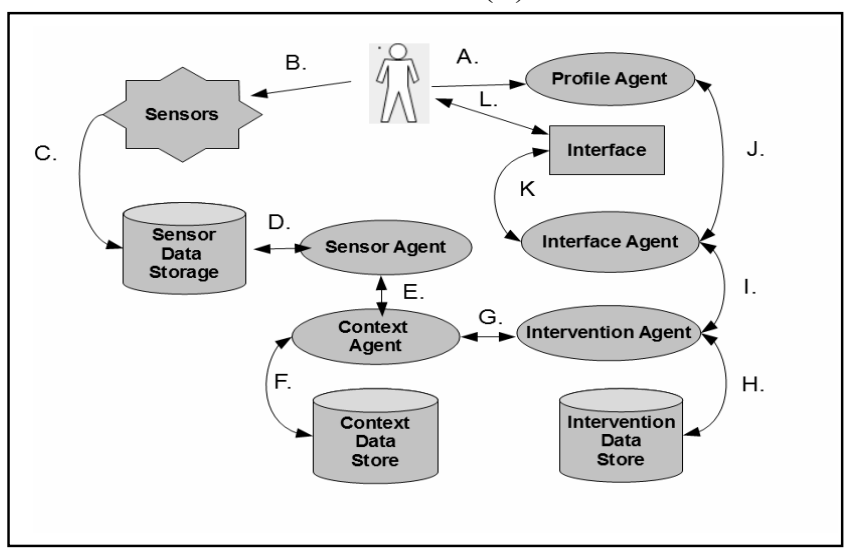

Figure 1. Multi-Agent Architecture

\section{1) The Sensor Agent}

Sensor data is deposited by the sensors in a sensor data store (C), in this case a MySQL database. The Sensor Agent retrieves sensor data from the sensor data store (D). The Sensor Agent sends a Sensor event messages (E) to the context agent that details the sensor event that has occurred and does not contain specific details of the sensor.

\section{2) The Context Agent}

The context agent determines the current context behind a sensor event, stores new context events and retrieves contextual events from a context data store $(F)$. It sends a message which corresponds to the detected context to the Intervention agent $(\mathrm{G})$

\section{3) The Intervention Agent}

The intervention Agent determines the interventions which should be made based on the contextual messages it receives from the context management agent. Once the interventions which are required have been determined, a message that details the interventions is sent to the Interface Agent.

\section{4) The Interface Agent}

This agent determines the content of the interface and the method in which interventions will be presented to the user and subsequently how the multi-agent system interacts with the user. The Interface agent interacts with the intervention agent (I), it makes use of intervention messages to determine the content of the interface and it interacts with the Profile agent $(\mathrm{J})$, to determine the correct method of interactions (Default, Visual, Sound based or Sight). The agent controls the content of the interface $(\mathrm{K})$ and receives feedback from the user through the interface $(\mathrm{L})$

\section{5) The Profile Agent}

The Profile Agent is responsible for determining the interaction profile that may be used and for managing and updating this profile. Once a profile has been set, a message is sent to the Interface agent detailing the current profile $(\mathrm{J})$.

\section{v. AN INDIVIDUAL'S REQUIREMENTS}

An important aspect of the multi-agent framework may be the ability to provide interaction and intervention methods that may be tailored to a specific individual or groups of people as they may have specific requirements. Examples are outlined by Table $\mathbf{I}$.

TABLE I. REQUIREMENTS BEING CONSIDERED

\begin{tabular}{|l|l|l|}
\hline \multicolumn{3}{|c|}{ Requirements under consideration } \\
\hline Requirement & \multicolumn{1}{|c|}{ Details } & \multicolumn{1}{c|}{ Interaction Method } \\
\hline $\begin{array}{l}\text { Limited } \\
\text { Hearing }\end{array}$ & $\begin{array}{l}\text { Not able to hear spoken } \\
\text { dialogue }\end{array}$ & $\begin{array}{l}\text { Make use of default text and } \\
\text { icons, no spoken dialogue will } \\
\text { be used }\end{array}$ \\
\hline $\begin{array}{l}\text { Very limited } \\
\text { Vision }\end{array}$ & $\begin{array}{l}\text { Not able to see the interface } \\
\text { or read text due to having } \\
\text { limited vision }\end{array}$ & $\begin{array}{l}\text { Make use of spoken dialogue } \\
\text { and interactions }\end{array}$ \\
\hline $\begin{array}{l}\text { Sligtly } \\
\text { limited } \\
\text { vision }\end{array}$ & $\begin{array}{l}\text { Not able to read small text } \\
\text { and icons }\end{array}$ & $\begin{array}{l}\text { Large text and icons, were } \\
\text { appropriate, make use of } \\
\text { spoken dialogue }\end{array}$ \\
\hline $\begin{array}{l}\text { No specific } \\
\text { requirements }\end{array}$ & $\begin{array}{l}\text { Able to read any size of text, } \\
\text { icons and can hear spoken } \\
\text { dialogue }\end{array}$ & $\begin{array}{l}\text { Combination of spoken } \\
\text { dialogue, standard text and } \\
\text { icons }\end{array}$ \\
\hline
\end{tabular}

These requirements are being considered in the current multi-agent implementation

\section{IMPLEMENTATION AND FUNCTIONALITY}

The multi-agent system is currently implemented in the Java Agent Development Environment (Jade) [15]. The main agents, Sensor Agent, Profile Agent, Context Agent, Intervention agent and Interaction Agent have been implemented and message passing has been tested. The agents 
are registered with a directory facilitator (a yellow pages service) and the messages that are related to the scenario are read, the agents process the messages and respond. The messages detailing their responses are outputted to the console. With the current version of the program the Jade agents read the contents of the messages and depending on this content a particular intervention or interaction message is displayed. By making use of string pattern matching the Profile Agent reads the content of the message and extracts the relevant profile and then is able to inform the Interface agent of the current profile. Currently four time periods have been set and these have an effect on the types of interventions and interactions that are made. For example, in relation to the scenario, the person has woken during the night; interventions will be relevant to finding out why they have woken up and to aid in helping the individual return to sleep.

\section{A. Results: Sensor Events and Messages}

A scenario was devised that is based on anonymized sensor data from an on-going research project named NOCTURNAL [16]. The details of the scenario follow: A person, who sleeps in a bed located in their living room wakes during the night and gets up from bed. They then enter the main hall and walk to the kitchen. The person then leaves the kitchen, re-enters the hall and enters the downstairs bathroom. They leave the bathroom, re-enter the hall and walk back to the living room and return to bed. The scenario was applied to the multi-agent framework and the 'no specific requirements' profile was followed. Table II details the events from the scenario, the sensor data that was consumed by the Sensor Agent, the corresponding sensor event messages that were sent by the Sensor Agent, the contextual messages that was sent by the Context Agent in response to corresponding Sensor Event Message, the resulting interventions that were selected by the intervention agent and the response that the Interaction Agent made so that the interventions may be displayed on an interface.

\section{DEPLOYMENT IN THE ENVIRONMENT}

The types of sensors that currently operate in the environment include PIR sensors (located in each room in a house), door contact sensors (connected to main doors, cupboard and fridge doors), bed-chair pressure sensors (located in beds and chairs of the house). The MAS may be able to operate in an environment that makes use of the same types of sensors and resulting sensor data is stored in a compatible format. Where a new building is being set up for AAL, a sensor type/ sensor data specification may be provided.

\section{FUTURE ADVANCEMENTS}

A future advancement may be to enable the agent framework to operate in an environment which contains many

TABLE II. SAMPLE RESULTS: MESSAGES SENT AND RECEIVED - PROFILE: NO SPECIFIC REQUIEMENTS

\begin{tabular}{|c|c|c|c|c|c|}
\hline $\begin{array}{l}\text { Event From } \\
\text { Scenario }\end{array}$ & Sensor Data & $\begin{array}{c}\text { Sensor Event } \\
\text { Messages }\end{array}$ & Contextual Message & Intervention Messages & Interaction Message \\
\hline Leaves bed & Bed-chair-OUT & $\begin{array}{l}\text { Out of bed and } \\
\text { Time: 00:00 }\end{array}$ & Person is out of bed at: 00:00 & $\begin{array}{l}\text { Time Intervention, Sleep } \\
\text { intervention, Assistance } \\
\text { intervention } \\
(\mathrm{A}),(\mathrm{C}),(\mathrm{F}),(\mathrm{D}),(\mathrm{G})\end{array}$ & $\begin{array}{l}\text { Time is } 00: 00 \text {, may be } \\
\text { advisable to return to bed, do } \\
\text { you require assistance, }\end{array}$ \\
\hline $\begin{array}{l}\text { Movement in } \\
\text { the living } \\
\text { room }\end{array}$ & $\begin{array}{l}\text { PIR-Living- } \\
\text { Room }\end{array}$ & $\begin{array}{l}\text { Entering Living } \\
\text { Room }\end{array}$ & $\begin{array}{l}\text { Person has entered the living } \\
\text { room }\end{array}$ & $\begin{array}{l}\text { Destination Intervention } \\
(\mathrm{A}),(\mathrm{B}),(\mathrm{E}),(\mathrm{I})\end{array}$ & $\begin{array}{l}\text { Do you need to go to the } \\
\text { Bathroom, Kitchen, or return to } \\
\text { bed }\end{array}$ \\
\hline $\begin{array}{l}\text { Movement in } \\
\text { the hall }\end{array}$ & PIR-Hall & Entering the Hall & Person has entered the Hall & $\begin{array}{l}\text { Destination Intervention } \\
(\mathrm{A}),(\mathrm{B}),(\mathrm{E}),(\mathrm{H})\end{array}$ & $\begin{array}{l}\text { Do you need to go to the } \\
\text { Bathroom, Kitchen or Living } \\
\text { Room }\end{array}$ \\
\hline $\begin{array}{l}\text { Movement in } \\
\text { the Kitchen }\end{array}$ & PIR-Kitchen & $\begin{array}{l}\text { Entering the } \\
\text { Kitchen }\end{array}$ & Person has entered the Kitchen & $\begin{array}{l}\text { Time intervention and Sleep } \\
\text { intervention } \\
(\mathrm{A}),(\mathrm{B}),(\mathrm{D}),(\mathrm{E}),(\mathrm{I})\end{array}$ & $\begin{array}{l}\text { Time is } 00: 10, \text { may be } \\
\text { advisable to return to bed }\end{array}$ \\
\hline $\begin{array}{l}\text { Movement in } \\
\text { hall }\end{array}$ & PIR-Hall & Entering the Hall & Person has entered the Hall & $\begin{array}{l}\text { Destination intervention } \\
(\mathrm{A}),(\mathrm{B}),(\mathrm{E}),(\mathrm{H})\end{array}$ & $\begin{array}{l}\text { Do you need to go to the } \\
\text { Bathroom, Kitchen or Living } \\
\text { Room }\end{array}$ \\
\hline $\begin{array}{l}\text { Movement in } \\
\text { downtairs } \\
\text { WC }\end{array}$ & $\begin{array}{l}\text { PIR- } \\
\text { Downstairs-WC }\end{array}$ & $\begin{array}{l}\text { Entering } \\
\text { downstairs WC }\end{array}$ & $\begin{array}{l}\text { Person has entered the downstairs } \\
\text { WC }\end{array}$ & $\begin{array}{l}\text { Assistance intervention, } \\
\text { Reminder intervention } \\
\text { (A),(B),(E),(I) }\end{array}$ & $\begin{array}{l}\text { Do you require assistance, } \\
\text { remember to wash hands }\end{array}$ \\
\hline $\begin{array}{l}\text { Movement in } \\
\text { the Hall }\end{array}$ & PIR-Hall & Entering the Hall & Person has entered the Hall & $\begin{array}{l}\text { Destination intervention } \\
(\mathrm{A}),(\mathrm{B}),(\mathrm{E}),(\mathrm{H})\end{array}$ & $\begin{array}{l}\text { Do you need to go to the } \\
\text { Bathroom, Kitchen or Living } \\
\text { room }\end{array}$ \\
\hline $\begin{array}{l}\text { Movement in } \\
\text { Living room }\end{array}$ & $\begin{array}{l}\text { PIR-Livng- } \\
\text { Room }\end{array}$ & $\begin{array}{l}\text { Entering Living } \\
\text { Room }\end{array}$ & $\begin{array}{l}\text { Person has entered the Living } \\
\text { Room }\end{array}$ & $\begin{array}{l}\text { Destination intervention } \\
(\mathrm{A}),(\mathrm{B}),(\mathrm{E}),(\mathrm{I})\end{array}$ & $\begin{array}{l}\text { Do you need to go to the } \\
\text { Bathroom, Kitchen, or return to } \\
\text { bed }\end{array}$ \\
\hline Enters bed & Bed-chair-IN & $\begin{array}{l}\text { In bed and Time: } \\
01: 00\end{array}$ & Person is in bed at 01:00 & $\begin{array}{l}\text { Standby Intervention, Timed } \\
\text { Sleep Intervention } \\
\text { (C), (J) }\end{array}$ & $\begin{array}{l}\text { Calming music being played } \\
\text { for } 5 \text { minutes, black out screen }\end{array}$ \\
\hline
\end{tabular}


people so that the assistance and support offered may be dynamically adapted based on who is currently interacting with the interface and be able to offer the assistance and support to multiple people at the same time. An issue with this that is being discussed is how to track the indivuals without invading their privacy or requiring the indivuals to wear an RFID tag. With the current multi-agent simulation assumptions are made regarding the sensor events and the resulting intervention and interactions messages. For example, it is being assumed that when a 'Bed-chair sensors-OUT' sensor message is received that the person has left their bed. In the real world an individual may be restless in their bed and may move about causing the bed sensor to be triggered. In the case of a 'PIR-Entering-Hall' message, it is being assumed that the individual is at least standing in the hall. In reality the individual may not be standing or even walking in the hall, they may be lying on the floor from a fall and the PIR sensors may be registering movement. The solution is to enable the agents to make use of multiple sensor data messages and process the messages at the same time so For example if the sensor agent receives a Bed-chair-out messages followed by a PIR-Living-Room message and a PIR-Hall message, this may be combined with other sensor inputs (pedometer, to detect walking) to enable the multi-agent framework to infer that the person has left their bed, walked through the living room (where their bed is located) and entered the hall.

\section{CONCLUSION}

Multi-Agent System research can help to support a person's routine through positive interactions and therapeutic interventions. This is particularly appropriate to older and vulnerable people. It is envisaged that the proposed multiagent system will be aware of the older person's current state in the environment, the context behind any activities they are carrying out and their current specified requirements. This will support and augment the older person's daily routine and provide assistance and support when they may be more vulnerable during the night. The multi-agent system provides a means to simulate the interactions that may occur between the specified agents in relation to scenarios, devised from real word sensor data. Context aware adaption of interfaces is important as it enables an individual to receive tailored assistance and support that is specific to their requirements. Combining research in the area of context aware systems with a Multi-Agent System (MAS) has certain advantages. The MAS can self-configure interventions which are made through an interface and further tailor these interventions. The method used to present the interventions is decided by providing the MAS with profile requirements and other relevant information including but not limited to, the current situation, detected context and location.

\section{References}

[1] A. Jaimes, \& N. Sebe (2007). Multimodal human-computer interaction: A survey. Computer Vision and Image Understanding, 108(1-2), 116134. Elsevier. DOI: 10.1016/j.cviu.2006.10.019

[2] H. Sun., V. De Florio., N. Gui and C. Blondia (2010). The missing ones: Key ingredients towards effective ambient assisted living systems. Journal of Ambient Intelligence and Smart Environments, 2(2), 109120. IOS Press.

[3] H. Nakashima., H. Aghajan and J.C. Augusto (2010). Handbook of Ambient Intelligence and Smart Environments H. Nakashima, H. Aghajan, J. C. Augusto, Eds. (Springer US, 2010)

[4] J. Nehmer, M. Becker, A. Karshmer \& R. Lamm. (2006), "Living assistance systems: an ambient intelligence approach", ICSE '06: Proceedings of the 28th international conference on Software engineering ACM, New York, NY, USA, pp. 43.

[5] A.K Dey. (2001) Understanding and Using Context. Personal and Ubiquitous Computing, 5(1), 4-7. DOI: 10.1007/s007790170019

[6] H. Sun, V. Florio, N Gui, \& C. Blondia. (2009). "Promises and Challenges of Ambient Assisted Living Systems," Information Technology: New Generations, Third International Conference on, pp. 1201-1207, 2009 Sixth International Conference on Information Technology: New Generations, 2009

[7] D.J. Cook, J.C. Augusto \&, V.R. Jakkula. (2009) Ambient intelligence: technologies, applications, and opportunities. Pervasive and Mobile Computing, 5(4), 277-298. DOI: 10.1016/j.pmcj.2009.04.001

[8] T, Kleinberger. Ambient intelligence in assisted living: enable elderly people to handle future interfaces. In Proceedings of the 4th international conference on Universal access in human-computer interaction: ambient interaction (UAHCI'07) (2007), Constantine Stephanidis (Ed.). SpringerVerlag, Berlin, Heidelberg, 103-112. rger, T, Becker., M. Ras, E.A. Holzinger \& P Muller. (2007)

[9] A. Mihailidis \& G.R. Fernie. Context-aware assistive devices for older adults with dementia. gerontechnology (2002); 2(2):173-188; doi:10.4017/gt.2002.02.02.002.00

[10] K. Benta, A. Hoszu, L. Vacariu \& C. Octavian (2009). "Agent based smart house platform with affective control", EATIS '09: Proceedings of the 2009 Euro American Conference on Telematics and Information SystemsACM, New York, NY, USA, pp. 1.

[11] W. Chun-dong., M. Xiu-liang,., and W. Huai-bin (2009). An intelligent home middleware system based on context-awareness. 2009 Fifth International Conference on Natural Computation, 165-169. Ieee. doi: 10.1109/ICNC.2009.566.

[12] A. D'Andrea., A. D'Ulizia., F. Ferri., and P. Grifoni (2009). A multimodal pervasive framework for ambient assisted living. ACM International Conference Proceeding Series.

[13] M. Blumendorf and S. Albayrak (2009). Towards a Framework for the Development of Adaptive Multimodal User Interfaces for Ambient Assisted Living Environments. In UAHCI '09: Proceedings of the 5th International on ConferenceUniversal Access in Human-Computer Interaction. Part II. Berlin, Heidelberg: Springer-Verlag, pp. 150-159.

[14] M. Bezold (2010). A framework for adapting interactive systems to user behavior. Journal of Ambient Intelligence and Smart Environments., 2(4), 369-387. Amsterdam, The Netherlands, The Netherlands: IOS Press., http://portal.acm.org/citation.cfm?id=1877752.1877755.

[15] F. Bellifemine., G. Caire., A. Poggi and Rimassa, G. 1., (2003). Jade-a white paper. EXP in search of innovation, 3(3), p.6-19.

[16] Carswell, W., McCullagh, P.J., Augusto, J.C., Martin, S., Mulvenna, M.D., Zheng, H, Wang, H.Y., Wallace, J.G., McSorley, K., Taylor, B., Jeffers, W.P., (2009) A Review of the Role of Assistive Technology for People with Dementia in the Hours of Darkness. Technology and Health Care, Volume 17, Number 4, pp. 281-304. 2009. IOS Press. 